\title{
KECERNAAN MINERAL ESENSIAL NATRIUM DAN KALIUM ANAK KUDA PACU (YEARLING) INDONESIA YANG DIBERI PAKAN LOKAL DAN PAKAN IMPOR
}

\author{
Jurgen E.K. Tampanguma, Y.L.R. Tulung*, A. Rumambi, W.B. Kaunang
}

Fakultas Peternakan Universitas Sam Ratulangi Manado 95115

\begin{abstract}
ABSTRAK
Penelitian ini bertujuan untuk mengetahui kemampuan anak kuda pacu dalam mencerna pakan baik pakan lokal dan impor di Desa Tonsewer dan Desa Kanonang selama 30 hari yang terdiri dari persiapan dan pengumpulan data. Data yang dikumpulkan yaitu jenis dan jumlah pakan (Natrium dan Kalium) yang diberikan pada ternak kuda pacu serta jumlah feses $\left(\right.$ ekor $^{-1}$ hari $\left.^{-1}\right)$, kemudian diambil sebanyak 10 sampel pakan lokal dan 10 sampel pakan impor. Hasil penelitian menunjukkan bahwa rataan kecernaan Natrium untuk pakan lokal sebesar $67.58 \%$ dan pakan impor $71.03 \%$, sedangkan kecernaan Kalium untuk pakan lokal sebesar $62,26 \%$ dan pakan impor $66,02 \%$. Kesimpulan dari penelitian ini adalah kecernaan Natrium dan Kalium pakan impor lebih baik dibandingkan dengan pakan lokal.
\end{abstract}

Kata Kunci: Kecernaan, Natrium, Kalium.

\begin{abstract}
ESSENTIAL MINERAL DIGESTIBILITY OF SODIUM AND POTASSIUM OF YEARLING FROM INDONESIA PROVIDED LOCAL FEED AND IMPORTED FEED. This study aims to determine the ability of
\end{abstract}

*Korespondensi (Corresponding author): Email: tulungyohannis@gmail.com racehorses to digest feed both local and imported feed in Tonsewer and Kanonang villages for 30 days consisting of preparation and data collection. The data collected were the type and amount of feed (Sodium and Potassium) given to race horses and the amount of feces (animal/day), then 10 local feed samples and 10 imported feed samples were taken. The results showed that the average of sodium digestibility for local feed was $67.58 \%$ and imported feed was $71.03 \%$, while Potassium digestibility for local feed was $62.26 \%$ and imported feed was $66.02 \%$. The conclusion of this study was that the digestibility of imported Sodium and Potassium feeds is better compared to local feed.

Keywords: Digestibility, Sodium, Potassium.

\section{PENDAHULUAN}

Kuda pacu sebagai ternak untuk diperlombakan dan mempunyai keunikan dalam hal mengkonsumsi pakan, sebab tujuan pemberian pakan adalah untuk mencapai prestasi yang baik pada saat pacuan, itulah sebabnya perlu diperhatikan jenis pakan maupun zat-zat makanan yang terkandung dalam pakan. Kuda merupakan salah satu jenis ternak besar yang termasuk hewan herbivore non-ruminansia (Hendri et 
al., 2012). Pemeliharaan kuda pacu di Indonesia termasuk manajemen pemberian pakan di Indonesia sebagian besar masih mengacu pada pemberian pakan yang dilakukan oleh negara-negara maju, oleh karena para peternak kuda lebih mengandalkan pemberian bahan baku pakan impor (Pongoh et al., 2015). Bahan baku pakan lokal menurut hasil-hasil analisis kandungan zat-zat makanan tidak kalah dibandingkan dengan komposisi zatzat makanan dari negara luar (Mende et al., 2015). Apabila dilihat dari hasil yang diperoleh pada saat pacuan, ternyata penggunaan pakan lokal tidak jauh berbeda dengan kuda yang menggunakan pakan impor (Tulung, 2012).

Mineral merupakan elemen-elemen atau unsur-unsur kimia selain dari karbon, hidrogen, oksigen dan nitrogen yang jumlahnya mencapai $95 \%$ dari berat badan. Jumlah seluruh mineral dalam tubuh hanya sebesar 4\% (Piliang, 2002). Kuda membutuhkan $\mathrm{Na}$ untuk glukosa dan transportasi asam amino, mempertahankan cairan tubuh, dan asam-basa keseimbangan (Coenen, 2005). Almatzier (2005) menyatakan natrium berperan pula dalam absorpsi glukosa dan sebagai alat angkut zat-zat gizi lain melalui membran, terutama melalui dinding usus sebagai pemompa natrium. $\mathrm{Na}$ bisa menjadi gizi dalam makanan dan memastikan bahwa garam disediakan pada ternak untuk memenuhi kebutuhan natrium (Eaton et al., 2010).

Kalium bersama sama dengan klorida berfingsi membantu menjaga tekanan asmotik dan keseimbangan asam basa dalam menjaga cairan intraseluler dan sebagian terikat dengan protein. Oleh karena itu, ketika diberikan hijauan pada tingkat yang direkomendasikan setidaknya $1-2 \%$ dari berat badan, persyaratan pemeliharaan kalium dapat dipenuhi oleh sebagian besar kuda-kuda yang tidak digunakan. Kecernaan natrium, kalium, dan klorida yang nyata masing-masing sekitar 90, 80, dan 90\%, menunjukkan pemanfaatan yang efisien dari makromineral ini oleh kuda. Kalium juga merupakan mineral yang bermanfaat bagi tubuh yaitu berfungsi untuk mengendalikan tekanan darah (Yaswir dan Ferawati, 2012).

\section{MATERI DAN METODE PENELITIAN}

Penelitian ini dilakukan di Desa Tonsewer Kecamatan Tompaso Barat dan Desa Kanonang Kecamatan Kawangkoan, Kabupaten Minahasa dari bulan Maret sampai dengan bulan April 2018. Ternak yang digunakan dalam penelitian ini adalah 20 ekor anak kuda pacu umur 13 - 24 bulan dengan rataan bobot 100 - $150 \mathrm{~kg}$. Ternak yang digunakan dalam penelitian ini 10 
ekor ternak yang mengkonsumsi pakan lokal dan 10 ekor ternak yang mengkonsumsi pakan impor. Penelitan ini menggunakan metode experimen, teknik pengambilan data yaitu, pengamatan langsung melalui metode koleksi total di lokasi peternak kuda pacu untuk pengambilan sampel pakan dan feses ouput.

Data yang dikumpulkan yaitu jenis dan jumlah pakan yang terdiri dari Natrium dan Kalium yang diberikan pada ternak kuda pacu serta jumlah feses (g.ekor ${ }^{-1}$.hari ${ }^{-1}$ ). Variabel yang diamati dalam penelitian ini adalah kecernaan Natrium dan kecernaan Kalium. Kecernaan (Na) dan (K) dihitung berdasarkan rumus (Banerjee, 1978):

$\frac{\text { Na yang dikonsumsi }- \text { Na dalam feses }}{\text { Na yang dikonsumsi }} \times 100 \%$

$\frac{\mathrm{K} \text { yang dikonsumsi }-\mathrm{K} \text { dalam feses }}{\mathrm{K} \text { yang dikonsumsi }} \times 100 \%$

Data hasil penelitian dianalisis dengan menggunakan uji t-test: twoSample Assuming Unequal Variances.

\section{HASIL DAN PEMBAHASAN}

Rataan jumlah konsumsi Natrium dan Kalium pakan lokal dan pakan impor dapat dilihat pada Tabel 1.

Pada Tabel 1 ternyata jumlah konsumsi bahan kering pakan menunjukan adanya perbedaan antara pakan lokal dan pakan impor. Hasil analisis uji $\mathrm{t}(t$-test $)$ twoSample Assuming Equal Variances menunjukkan adanya perbedaan yang nyata $(p<0.05)$ antara konsumsi bahan kering pakan impor dibandingkan dengan pakan lokal. Tulung (2012) mengemukakan bahwah nilai biologis pakan menentukan jumlah konsumsi.

\section{Pengaruh Perlakuan Terhadap Kecernaan Natrium (Na)}

Data Menunjukkan rataan kecernaan natrium $(\mathrm{Na})$ untuk pakan lokal sebesar $67.58 \%$ dan pakan impor $71.03 \%$, hasil uji $\mathrm{t}$ (t-test) Two-Sample Assuming Unequal

Tabel 1. Angka Rataan Jumlah Konsumsi Bahan Kering Anak Kuda Pacu

\begin{tabular}{lcc}
\hline \multirow{2}{*}{ Konsumsi $(\mathrm{g})$} & \multicolumn{2}{c}{ Perlakuan } \\
\cline { 2 - 3 } & Pakan lokal & Pakan impor \\
\hline Konsentrat & $4325^{\mathrm{a}}$ & $5078^{\mathrm{b}}$ \\
Hijauan & $1490^{\mathrm{a}}$ & $1334^{\mathrm{b}}$ \\
Total Konsumsi & 5816 & 6411 \\
\hline
\end{tabular}

Keterangan: Angka pada baris yang sama dengan superskrip yang berbeda menunjukan hasil yang berbeda nyata $(\mathrm{p}<0,05$ 
Tabel. 2. Rataan Kecernaan Na dan K Anak Kuda Pacu yang Mengkonsumsi Pakan Lokal dan Impor

\begin{tabular}{lcc}
\hline \multirow{2}{*}{ Kecernaan $(\%)$} & \multicolumn{2}{c}{ Perlakuan } \\
\cline { 2 - 3 } & $67.58^{\mathrm{a}}$ & Pakan Impor \\
\hline Kecernaan Natrium $(\mathrm{Na})$ & $62.26^{\mathrm{a}}$ & $61.03^{\mathrm{b}}$ \\
Kecernaan Kalium $(\mathrm{K})$ & $66.02^{\mathrm{b}}$ \\
\hline \multicolumn{2}{l}{ Keterangan: Angka pada baris yang sama dengan superskrip yang berbeda menunjukan hasil } \\
\multicolumn{2}{c}{ yang berbeda nyata $(\mathrm{p}<0,05)$ kecernaan Natrium pakan lokal }
\end{tabular}

Variances menunjukkan bahwa kecernaan Natrium pakan impor berbeda nyata lebih tinggi $(\mathrm{p}<0,05)$ dibandingkan dengan pakan lokal.

Berdasarkan hasil uji tersebut, menunjukkan bahwa, konsumsi pakan impor anak kuda pacu memiliki nilai kecernaan Natrium yang nyata lebih tinggi dibandingkan dengan pakan lokal, hal ini disebabkan karena rataan jumlah konsumsi pakan impor lebih tinggi dari pakan lokal walaupun kandungan energi dari kedua jenis pakan tersebut tidak jauh berbeda. Kuda membutuhkan natrium untuk transportasi asam amino, mempertahankan cairan tubuh dan asam basa keseimbangan. Apabila hijauan makanan ternak mengandung Na tinggi akan mempengaruhi palatabilitas hijauan pakan tersebut.

\section{Pengaruh Perlakuan Terhadap Kecernaan Kalium (K)}

Rataan kecernaan kalium $(\mathrm{K})$ untuk pakan lokal sebesar $62,26 \%$ dan pakan impor $66,02 \%$, hasil uji t (t-test) Two-
Sample Assuming Unequal Variances, menujukkan bahwa kecernaan Kalium pakan impor berbeada nyata lebih tinggi $(\mathrm{p}<0,05)$ dibandikan dengan kecernaan Kalium paka lokal. Berdasarkan hasil uji tersebut, ini berarti konsumsi pakan impor anak kuda pacu memiliki angka kecernaan Kalium yang nyata lebih tinggi dibandingkan dengan pakan lokal. Jansen (2002) mengemukakan bahwa Penelitian menggunakan perlakuan pakan impor memberi respon angka kencernaan lebih tinggi karena kandungan nutrisi dari pada pakan impor lebih baik dari pada perlakuan pakan lokal.

Menurut Harris dan Schott (2013) bahwa kalium berperan sebagai elektrolit bermuatan positif utama. Salah satu peran utama kalium adalah menjaga kepekaan saraf dan otot pada tingkat normal, tidak terlalu reaktif atau terlalu reaktif terhadap impuls yang menyuruh mereka berkontraksi 


\section{KESIMPULAN}

Berdasarkan hasil penelitan ini dapat disimpulkan bahwa kecernaan Natrium dan Kalium pakan impor untuk anak kuda pacu Indonesia lebih baik dibandingkan dengan pakan lokal.

\section{DAFTAR PUSTAKA}

Almatsier, S. 2005. Pinsip dasar ilmu gizi. Jakarta: Gramedia Pustaka Utama.

Banerjee. 1978. Animal Nutrition. Oxford LBH Publ. Co. Calcutta. Bombay. New Delhi.

Coenen, M. 2005. Exercise and stress: impact on adaptive processes involving water and electrolytes. Livestock Production Science 92: 131-145.

Eaton, M. D., D.R. Hodgson, D.L. Evans, W.L. Bryden, R.J. Rose. 2010. Effect of a diet containing supplementary fat on the capacity for high intensity exercise. Equine Veterinary Journal, 27: 353-356.

Harris, P.A. dan H.C. Schott. 2013 Nutritional management of elite endurance horses. In: Geor, R., Harris, P.A. and Coenen, M., eds., (2013). Equine Applied and Clinical Nutrition. China: Saunders Elsevier, pp. $272-288$

Hendri, H., S. Suardi, A. Mikail. 2012. Perbandingan performans kuda lokal dan turunan Thoroughbred di kota Payakumbu. Fakultas Peternakan. Universitas Andalas
Padang. Jurnal Peternakan Indonesia 14(3): 441-446.

Jansen, W.L., J. van der Kuilen, S.N.J. Geelen, A.C. Beynen. 2002. Dietary soyabean oil depresses the apparent digestibility of fire in trotters when substituted for an iso energetic amount of corn starch or glucose. Equine Vet Journal 34: 302-305.

McCutcheon, L.J. dan R.J. Geor. 1996 Sweat fluid and ion losses in horses during training and competition in cool vs. hot ambient conditions: implications for ion supplementation. Equine Veterinary Journal, 22: 54-62.

Mende, I.S., Y.L.R. Tulung, J.F. Umboh, W.B. Kaunang 2015. Kecernaan energi, protein dan mineral kalsium dan fosfor kuda pacu Minahasa yang diberikan pakan lokal dan impor. Zootec 35(1): 30-38.

Pongoh, V.M,B., Y.L.R. Tulung, L.J.M Rumokoy. 2015. Uji karakteristik fisik dan kimia pakan lokal dan impor Kuda Pacu Minahasa. Zootec 35(1) : 62-71.

Piliang, W. G., 2002. Nutrisi Mineral. Edisi kelima. Pusat Antar Universitas, Institut Pertanian Bogor. Bogor

Tulung, Y.L.R. 2012. Kebutuhan Energi dan Nutrien Kuda pacu Indonesia dan Aplikasi pada Formulasi Ransum Berbasis Pakan Lokal. Disertasi. Program Pascasarjana Institut Pertanian Bogor.

Yaswir, R. Dan I. Ferawati. 2012. Fisiolog dan gangguan keseimbangan natrium, kalium dan klorida serta pemeriksaan laboratorium. Jurnal Kesehatan Andalas 1(2): 80-85 